\title{
Fine needle aspiration cytology - a boon in the diagnosis of cutaneous metastasis
}

\author{
Giriyan S.S. ${ }^{1}$, Chandan R.H. ${ }^{2}$, Padgaonkar K,G. ${ }^{3}$ \\ ${ }^{1}$ Dr. Sujata S. Giriyan, Professor and Head, ${ }^{2}$ Dr. Rajesh H. Chandan, Associate Professor, ${ }^{3}$ Dr. Kalyani G. Padgaonkar, \\ Postgraduate; all authors are affiliated with Department of Pathology, Karnataka Institute of Medical Sciences, Hubli, \\ Karnataka, India.
}

Address for Correspondence: Dr. Kalyani G. Padgaonkar, Email: kal.lifestyle1991@gmail.com

\begin{abstract}
Introduction: Cutaneous metastasis is an uncommon manifestation of visceral malignancy (0.8-5\%) indicating a grave prognosis. Cutaneous metastasis manifests as nodules, ulceration, cellulitis or fibrotic processes. Lesions are solitary or multiple frequently found near the primary tumour. The most frequent organs presenting with cutaneous metastasis are breast, skin (melanoma), lung, colon, stomach, upper aerodigestive tract, kidney and the uterus. On histopathology, they can be classified as adenocarcinoma, squamous cell carcinoma, undifferentiated carcinoma and other miscellaneous types.Case Reports:The present series involves 3 cases of cutaneous metastasis diagnosed on FNAC. First case of osteosarcoma presenting as swelling in femoral region, second case as swelling in cervical region from cancer oesophagus and third case presented with swelling over sternum from an unknown primary. Conclusion:FNAC is the first line diagnostic procedure for diagnosis of cutaneous metastasis. It is inexpensive, simple and fast diagnostic tool confirming clinical diagnosis.
\end{abstract}

Keywords: Cutaneous metastasis, Fine Needle Aspiration Cytology, osteosarcoma deposits

\section{Introduction}

Cutaneous metastasis are consider uncommon in visceral malignancy but indicating poor prognosis [1$8,9,10]$. Although it was observed that incidence of cutaneous manifestation increses with older age [13]. Sometime they are the initial manifestation of visceral malignancies. [1,13].Fine Needle Aspiration Cytology (FNAC) is consider economic, easily available, non invasive, excellent method for early diagnosis of cutaneous manifestation. On the basis of this initial test we can proceed for more advanced test in presence of specific features indicating serious visceral malignancies $[19,20]$.

Here we report 3 cases of cutaneous metastasis.

\section{Case Reports}

A 21 Years male, known case of osteosarcoma of right proximal tibia operated with above knee amputation 2 years back presented with a painless swelling in the right groin for 15 days. On examination, subcutaneous swelling was present in the right femoral region measuring $2 \times 2 \mathrm{~cm}$ firm, mobile and non-tender.

On FNAC, the smears showed malignant tumour cells in singles and fragments which were highly pleomorphic with round to oval eccentric hyperchromatic irregular nucleus, 1-2 nucleoli and moderate amount of cytoplasm. Many anaplastic tumour giant cells with occasional osteoclastic giant cells were seen.

Scanty homogenous eosinophilic material was seen in a hemorrhagic background along with few lymphocytes. Hence the diagnosis of cutaneous deposits of osteosarcoma was made.

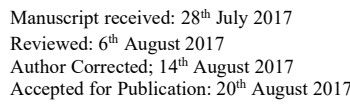




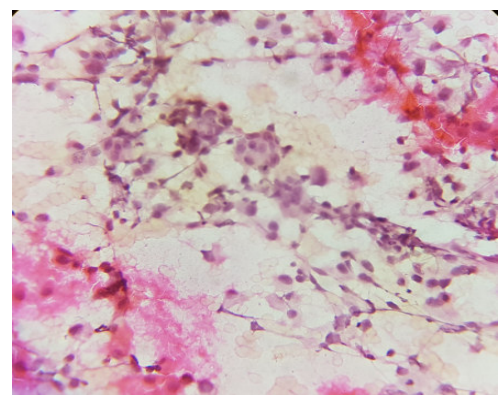

Figure 1- Microscopy showing tumour cells in fragments with highly pleomorphic nucleus (10X - Pap Stain)

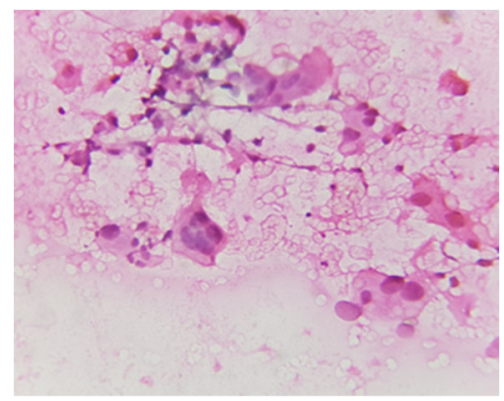

Figure 3- Microscopy showing osteoclastic giant cell $(40 \mathrm{X}-\mathrm{H} \& \mathrm{E})$

\section{Case Report}

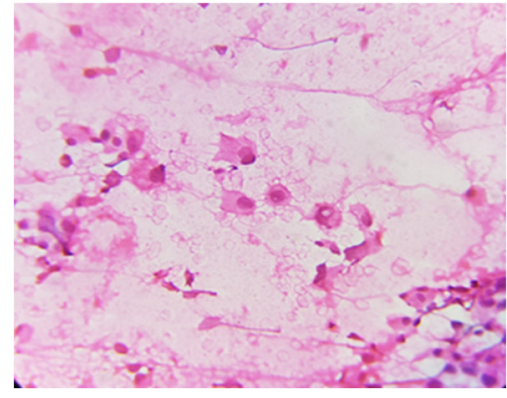

Figure 2- Microscopy showing round to oval eccentric hyperchromatic irregular nucleus (40X - H \& E)

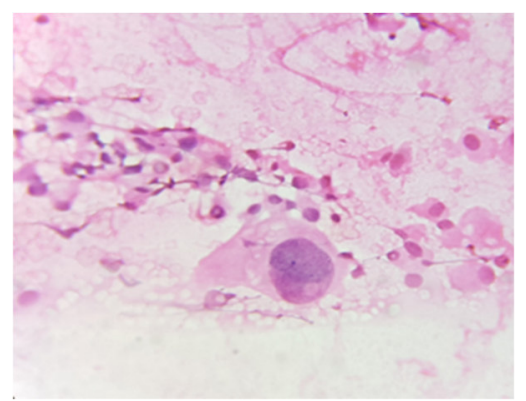

Figure 4- Microscopy showing anaplastic tumour giant cell $(40 \mathrm{X}-\mathrm{H} \& \mathrm{E})$

A 50 years male presented with a swelling in upper part of chest along with pain abdomen since 1 month. On examination, swelling was present over the upper end of sternum measuring $3 \times 3 \mathrm{~cm}$ cystic- firm, fixed to the underlying structures and muscle and was tender. On USG abdomen, hepatomegaly with well defined hypoechoic lesions was noted. On FNAC of the swelling, smears showed features of adenocarcinoma deposits with atypical cells arranged in groups, vague acini and singles. These cells had an increased $\mathrm{N}: \mathrm{C}$ ratio with large nucleus with coarse nuclear chromatin, 1-3 nucleoli and moderate amount of cytoplasm. USG guided FNAC of the liver mass showed features of papillary adenocarcinoma deposits.

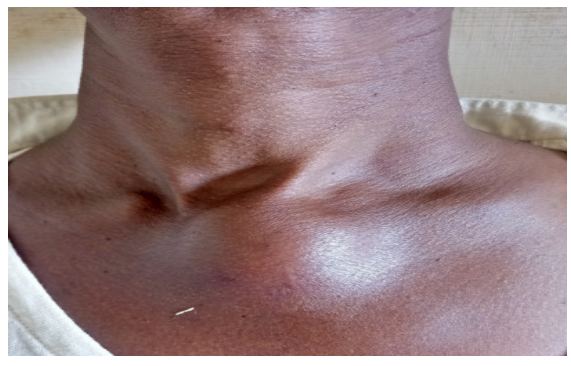

Figure 5-Clinical presentation

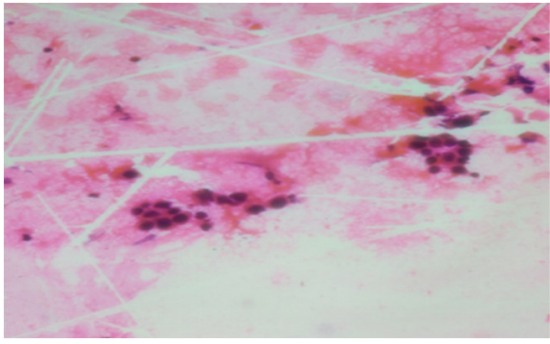

Figure 6- Microscopy showingwith atypical cells arranged vague acini $(10 \mathrm{X}-\mathrm{H} \& \mathrm{E})$

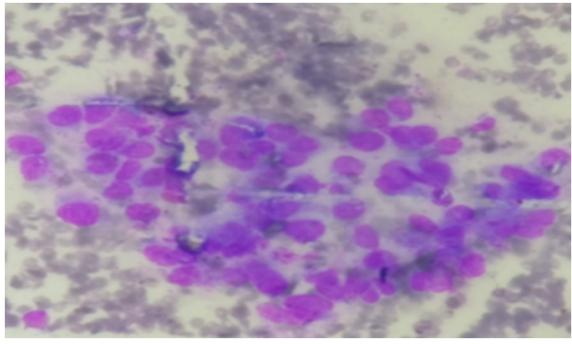

Figure 7- Microscopy showingwith atypical cells arranged in groups with cells with large nucleus with coarse nuclear chromatin, 1-3 nucleoli and moderate amount of cytoplasm (40X - Wright's stain) 


\section{Case Report}

A 62 years male known case of CA oesophagus on chemotherapy presented with swelling over right side of neck since one year. On examination, a hard irregular swelling measuring $5 \times 3 \mathrm{~cm}$ was present over right supraclavicular and cervical region which was fixed and nontender. On FNAC, smears were cellular showing malignant tumour cells in groups, acini and singles. These cells were pleomorphic with pleomorphic nucleus, coarse nuclear chromatin, prominent nucleoli and moderate amount of cytoplasm. Background was hemorrhagic with mixed inflammatory cell infiltrates. Diagnosis of cutaneous adenocarcinoma deposits was made.

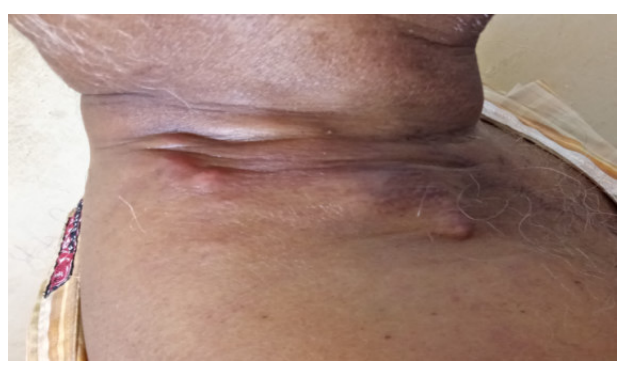

Figure 8- Clinical presentation

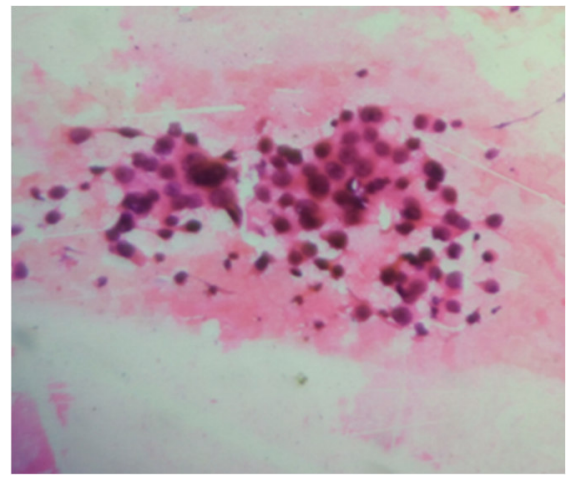

Figure 9- Microscopy showing malignant tumour cells in groups with pleomorphic nuclei (40X - H \& E stain)

\section{Discussion}

Cutaneous metastasis are consider uncommon in visceral malignancy but indicating poor prognosis $(0.8$ $5 \%$ ). It manifests as nodules, ulceration, cellulitis or fibrotic processes. Lesions are solitary or multiple frequently found near the primary tumour $[1,8,9,10]$.

Chest and abdomen is the commonest site of cutaneous metastases reported in the literature followed by head and neck[1]. The most common malignancies to metastasize to skin are lung followed by Gastrointestinal tract, melanoma, RenalCell Carcinoma and carcinoma of oral cavity in males.

Breast followed by colon, melanoma, lung,ovary and sarcoma are the common primary sites in females [1,9]. Age ranges between 2-76 years [1,12]. On Histopathology, they can be classified as adenocarcinoma, squamous cell carcinoma, undifferen-

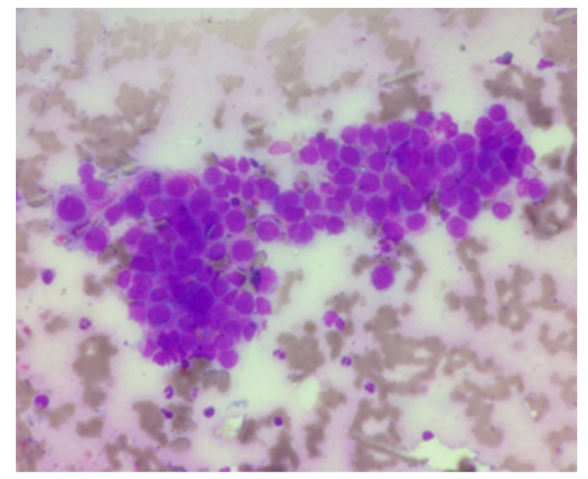

Figure 10- Microscopy showing malignant tumour cells in groups with pleomorphic nucleus, coarse nuclear chromatin, prominent nucleoli and moderate amount of cytoplasm (40X - Wright's stain)

tiated carcinoma and other miscellaneous types[11]. Adenocarcinoma from various organs is the commonest to metastasize to skin[1,10].

Lymphatic spread is most common route of transmission to regional part of the body. While distant spread occur by hematogenous spread $[1,14]$.

Skin metastases are usually occur to chest in lung malignancies that is close to primary tumor. Similarly Abdomen skin \& lower back skin involvement occur in GIT \& Renal tumour respectively. [1,15].

It is also very important that metastatic lesion to be differentiated from primary skin tumour. Presence of pools of extracellular mucin, signet cells and three dimensional papillae represent metastases rather than primary in case of adeno-carcinoma. 


\section{Case Report}

Metastases is usually located in the deeper dermis and subcutaneous tissue and theyare free from the overlying skin[1,10]. In our study, the deposits presented as cutaneous lesions. They are of diagnostic importance as they can be the first manifestation of visceral malignancy[5]. In our study, one case was of osteosarcoma deposits and 2 cases were of adenocarcinoma deposits.

Osteosarcoma tends to extend to the surrounding tissues and metastasis through bloodstream occurs to lung, other bones, pleura and heart[8]. Cutaneous metastasis is rare. It is recomonded that skin nodules to be identified by FNAC in these cases \& malignant chemotherapy to be included for treatment purpose [2] Cutaneous metastasis is a finding indicating progresssivenessof the disease[3].

Cutaneous metastasis although rare is the first presenting sign in occult primary. It is usually a sign of terminal stage of malignant disease. Cytology helps in early diagnosis and prompt initial evaluation and treatment[7]. Many authors have been found that skin manifestation are early sign of many cancers like cancers of lung, kidney and ovary [16]. Even in many cases it is not possible to identify primary source of tumour even after autopsies[1,17,18]. Lymph node metastasis occurs early in cancer oesophagus and is the main reason for treatment failure. Blood borne metastasis can be seen in liver, lung and adrenal glands[8]. In Oesophagus carcinoma spread to skin as metastasis is very uncommon only in lss than $0.5 \%$ of cases. It is the oesophageal adenocarcinoma, which is more prone to be associated with cutaneous metastases[4].

\section{Conclusion}

FNAC should be consider supportive measure in diagnosis of some diseses. Specially if it is located in the skin of chest, abdomen, neck or lower back. It may offer a clue to underlying malignancy in unsuspected cases.

\section{Funding: Nil, Conflict of interest: None. Permission of IRB: Yes}

\section{References}

1. Karki S, Pathak R, Manandhar U, Koirala S. Metastatic cutaneous and subcutaneous lesions: Analysis of cases diagnosed on fine needle aspiration cytology. Journal of Pathology of Nepal. 2011;1:37-40.
2. Bahadur AK, Ouseph MM, Rathi AK, Sharan GK, Sharma P, Shyama J et al. Osteosarcoma with cutaneous metastases. A case report. Acta cytol. 2007; 1: 102-6.

3. Shaheen O, Ghibour A, Alsaid B. Esophageal Cancer Metastases to Unexpected Sites: A Systematic Review. Gastroenterology Research and Practice. 2017;2017: 1657310. doi:10.1155/2017/1657310.

4. Chauhan A, Sharma AK, Sunita BS. Cutaneous metastasis as primary presentation in unsuspected carcinoma esophagus: Report of two cases. J Can Res Ther. 2015;11:667

5. Mazumder G, Nath S. Role of fine needle aspiration cytology (FNAC) in the diagnosis of skin and subcutaneous lesions: a retrospective analysis. J Evolution Med Dent Sci 2016; 5(5): 292-295, DOI: 10. $14260 /$ jemds/2016/63

6. Mendonca B, Fernandes H, Rahim S, Ali S, Hegdekatte N. Cytology- a boon in the diagnosis of cutaneous and subcutaneous metastatic nodules. International Journal of Recent Trends in Science and Technology. 2015March; 14(2): 455-457.

7. Rosai and Ackermann surgical pathology, $10^{\text {th }}$ edition, Volume 2.

8. Yasin SB, Bashir N, Khan SP. Evaluation of Metastatic Cutaneous Lesions on Fine Needle Aspiration Cytology: A Five Year Study. Annals of Applied Bio-Sciences. 2017 ; 4(1)

9. Erdemir AT, Atılganoglu U, Onsun N, Somay A. cutaneous metastases from gastric adenocarcinoma. indian journal of dermatology 2011;56(2):236-237.

10. Sharma S, Kotru M, Yadav A, Chugh M, Chawla A, Makhija M. Role of fine-needle aspiration cytology in evaluation of cutaneous metastases. Diagn Cytopathol. 2009 Dec; 37 (12): 876-80. doi: 10.1002/dc.21119.

11. Fyrmpas G, Barbetakis N, Efstathiou A, Konstantinidis I, Tsilikas C. Cutaneous metastasis to the face from colon adenocarcinoma. Case report. Int Semin Surg Oncol. 2006 Feb 2;3:2. doi: 10.1186/ 1477-7800-3-2.

12. Bansal R, Patel T, Sarin J, Parikh B, Ohri A, Trivedi P.Cutaneous and subcutaneous metastases from internal 


\section{Case Report}

malignancies: an analysis of casesdiagnosed by fine needle aspiration. Diagn Cytopathol. 2011 Dec; 39 (12): 882-7. doi: 10.1002/dc.21485. Epub 2010 Nov 2.

13. Rolz-Cruz G, Kim CC. Tumor invasion of the skin. Dermatol Clin. 2008 Jan;26(1):89-102, viii.

14. Gattuso P, Castelli MJ, Reyes CV, Reddy V. Cutaneous and subcutaneousmasses of the chest wall: a fine-needle aspirationstudy.Diagn Cytopathol. 1996 Dec; 15(5):374-6.

15. Brownstein MH, Helwig EB.Patterns of cutaneousmetastasis. Arch Dermatol. 1972 Jun;105(6):862-8.

16. Schwartz RA. Cutaneous metastatic disease. J Am Acad Dermatol.1995 Aug;33(2Pt1):161-82;quiz 183-6.
17. Didolkar MS, Fanous N, Elias EG, Moore RH. Metastaticcarcinomas from occultprimary tumors. A study of 254 patients. Ann Surg. 1977 Nov;186(5): 625-30.

18. Osteen RT, Kopf G, Wilson RE. In pursuit of the unknown primary. Am J Surg. 1978 Apr;135(4):494-7.

19. Geramizadeh B, Marzban S, Karamifar N, Omidifar N, Shokripour M, et al. Diagnosis of Subcutaneous Metastatic Deposits by Fine Needle Aspiration. J Cytol Histol. 2012; 3:151

20. David O, Kluskens L, Reddy V, Gattuso P. Malignantcutaneous and subcutaneous abdominal walllesions: a fine-needle aspirationstudy. Diagn Cytopathol. 1998 Oct;19(4):267-9.

\section{How to cite this article?}

Giriyan S.S, Chandan R.H, Padgaonkar K,G. Fine needle aspiration cytology - a boon in the diagnosis of cutaneous metastasis. Trop J Ophthalmol Otolaryngol.2017;2(2):27-31. doi: 10.17511/jooo.2017.i02.03. 